http://dx.doi.org/10.15762/ZH.2015.43

SZCZEPAN WIERZCHOSŁAWSKI

(Uniwersytet Mikołaja Kopernika w Toruniu)

\title{
ŻOŁNIERSKIE PERYPETIE POLSKIEGO KSIĘDZA WŁADYSŁAWA ŁĘGI W DOBIE PIERWSZEJ WOJNY ŚWIATOWEJ
}

Słowa kluczowe: 1914-1919, służba sanitarna, kapelani wojskowi, armia pruska, front, niewola, obozy jenieckie, armia gen. Józefa Hallera

Działalność naukowa księdza Władysława Łęgi (1889-1960) została szeroko omówiona w publikacji dotyczącej działaczy Towarzystwa Naukowego w Toruniu w latach 1875-1975². Mniej zajmowano się natomiast jego uczestnictwem w pierwszej wojnie światowej w mundurze żołnierza niemieckiego, a potem armii polskiej gen. Józefa Hallera. A mamy do dyspozycji jego bezpośrednie wrażenia opublikowane w 1922 r. $^{2}$

Przypomnijmy, że ks. W. Łęga urodził się w rodzinie nauczyciela pracującego w jednoklasowej szkole w Miranach (powiat sztumski). Elementarne wykształcenie uzyskał w szkole ojca, natomiast gimnazjalne w Rogoźnie Wielkopolskim, gdzie mieszkała jego najbliższa rodzina. Tam nazywano go Kaszubem³ ${ }^{3}$ W 1906 r. wstąpił do tajnego kółka filomackiego i działał w nim aż do matury w $1910 \mathrm{r}^{4}$ W tym roku podjął naukę w Wyższym Seminarium Duchownym w Pelplinie, spotykając tam cenionych pedagogów, ks. Stanisława Kujota ${ }^{5}$ i ks. Alfonsa Mańkowskiego ${ }^{6}$, którzy rozbudzili w nim zainteresowania badaniami historycznymi. Dnia 29 III 1914 r. uzyskał święcenia kapłańskie i w kwietniu podjął w Szczuce pod Brodnicą pracę duszpasterską jako wikary, przerwaną w 1915 r. powołaniem do armii niemieckiej?.

\footnotetext{
${ }^{1}$ Jan Powierski, Władysław Łęga 1889-1960, [in:] Działacze Towarzystwa Naukowego w Toruniu 1875-1975, red. Marian Biskup, Warszawa-Poznań 1975, s. 309-400.

${ }^{2}$ Władysław ŁĘGA, Z mych wrażeń wojennych, Grudziądz 1922.

${ }^{3}$ Książnica Miejska w Toruniu (dalej cyt. KM), Towarzystwo Naukowe (dalej cyt. TN), sygn. 286/186, nr 20, życiorys własny W. Łęgi; Władysław ŁęGA, Cienie i blaski lat szkolnych. Wspomnienia Polaka $z$ Prus Wschodnich, oprac. Jan Walkusz, Wejherowo 1997.

${ }^{4}$ W. ŁĘGA, Cienie i blaski, s. 130133.

${ }^{5}$ Kazimierz Jası́́ski, Stanisław Kujot (1845-1914), [in:] Działacze Towarzystwa Naukowego $w$ Toruniu 1875-1975, s. 85-179.

${ }^{6}$ Krystyna Podlaszewska, Alfons Mańkowski (1870-1941), [in:] ibid., s. 217-280.

${ }^{7} \mathrm{KM}$, TN, sygn. 286/186, nr 4, 8, 20.
} 
W sierpniu 1914 r. w wyniku odwrotu wojsk niemieckich po bitwie pod Gąbinem (20 sierpnia) spora część Prus Wschodnich znalazła się w rękach rosyjskich ${ }^{8}$, a Szczuka w pasie „ziemi niczyjej” i stała się miejscem rekonesansów rosyjskich patroli, które wbrew obiegowym opiniom poprawnie zachowywały się w stosunku do Polaków, natomiast przeciwnie wobec Niemców9. Polaków rozpoznawali po „świętych obrazkach” wiszących na ścianach izb mieszkalnych lub też po modlitwach w języku polskim. W związku z tym ludność niemiecka w szybkim tempie uczyła się modlitw katolickich po polsku i dokonywała zakupu świętych obrazów, zawieszając je w swych domach na wypadek wizyty rosyjskich patroli ${ }^{10}$.

Zarządzenie przez niemieckie władze ewakuacji ludności za Wisłę, mimo jej późniejszego odwołania, wywołało jednak zaniepokojenie, tym bardziej że ze wschodu szły kolumny uciekających przed Rosjanami ${ }^{11}$. W końcu sierpnia (23-29) 1914 r. odbyła się sławna bitwa 8. Armii niemieckiej dowodzonej przez gen. Paula von Hindenburga z 2. Armią rosyjską gen. Aleksandra Samsonowa pod Tannenbergiem, zakończona sromotną klęską Rosjan. Kolejna wielka bitwa rozegrana między tymi wojskami, trwająca od 8 do 15 września, zwana bitwą nad jeziorami mazurskimi, doprowadziła do wypchnięcia Rosjan z Prus Wschodnich ${ }^{12}$, ale nadal miejscowa ludność odczuwała specyfikę czasów wojny.

Spokojną, jak na warunki wojenne, egzystencję wikarego w Szczuce diametralnie zmieniło wręczone mu 12 I 1915 r. wezwanie rekrutacyjne do służby wojskowej ${ }^{13}$. Rozpoczął służbę jako rekrut-szeregowiec wpierw w Toruniu, a potem odesłano go do 128. Pułku Piechoty w Gdańsku, gdzie poddany został wojskowemu szkoleniu. Poznał wówczas, że hierarchia obowiązuje nie tylko w czasie ćwiczeń, lecz także w kantynie, w której dla szeregowców były przeznaczone stoły i ławy z ciosanych desek, a dla podoficerów specjalny estetyczny, nakryty obrusem stolik ${ }^{14}$.

Przysięgę wojskową rekruci złożyli w trzech grupach: Hanzjatów (?), Prusaków i Żydów; każda z nich według odrębnej formuły. Kolejnym etapem żołnierskiej doli ks. W. Łęgi był kurs na sanitariusza, który prowadził podoficer będący w cywilu zawodowym aktorem, stąd wiedza i umiejętności kursantów zostały ograniczone do leczenia odmrożeń, reumatyzmu i opatrywania nieskomplikowanych ran. Po złożeniu wniosku o umożliwienie mu posługi duszpasterskiej ks. W. Łęga został przeniesiony do Nowego Portu, gdzie wreszcie odbył autentyczny kurs sanitariusza ${ }^{15}$.

\footnotetext{
${ }^{8}$ Michał KLIMEcKi, Operacje wojenne na ziemiach polskich w latach 1914-1915, [in:] U źródeł niepodległości: 1914-1918. Z dziejów polskiego czynu zbrojnego, red. Piotr StAWEcKi, Warszawa 1988, s. 91.

${ }^{9}$ W. ŁĘGA, Z mych wrażeń, s. 6-7.

${ }^{10}$ Ibid., s. 7.

${ }^{11}$ Ibid.

${ }^{12}$ M. KLIMECKI, op.cit., s. 94.

${ }^{13} \mathrm{~W}$. ŁĘGA, Z mych wrażeń, s. 9.

${ }^{14}$ Ibid., s. 12.

${ }^{15}$ Ibid., s. 13-14.
} 
Władysławowi Łędze jako kapłanowi przysługiwały dystynkcje oficerskie, których jednak nie nadano mu z niewiadomych powodów. Od 1 IV 1915 r. został przydzielony do służby jako sanitariusz, zakrystian i kapelan pomocniczy przy kapliczce samochodowej 10. Armii, dowodzonej przez gen. Hermanna von Eichhorna. Ten lekko opancerzony samochód, mający wbudowany w tylnej części ołtarz, był darem wiernych diecezji chełmińskiej dla duszpasterstwa polowego armii niemieckiej i zwał się „Emanuel - Culm”. Jego załogę stanowiło dwóch księży, niosących posługę duszpasterską żołnierzom frontowym, i dwóch kierowców ${ }^{16}$. Ks. W. Łęga wyruszył więc w trasę z Gdańska w kierunku wschodnim przez Tczew, Malbork, Elbląg, Frombork ku Braniewu, a następnie do Królewca i Wystruci. W drodze spowiadał także cywilów, w większości uchodźców z Królestwa Polskiego i Galicji, ewakuowanych do obszarów, na których nie spodziewano się prowadzenia walk ${ }^{17}$. Przez Darkiejmy, Gołdap i wyludnione Olecko kapliczka dotarła do ziem dawnego Królestwa Polskiego i Suwałk, odnotowując fatalny stan tamtejszych dróg. Stamtąd pojechała na oddalony o $7 \mathrm{~km}$ front, gdzie W. Łęga mógł nieść pokrzepienie walczącym. Żołnierze nazywali jego ruchomą kapliczkę m.in. „Sündenabwehrkanone” lub „Hallelujakutsche”" . Niejednokrotnie służyła także do transportu rannych, ratując nie tylko dusze, lecz także ciało. Ostatecznie dotarła aż do Lwowa.

Ksiądz W. Łęga zauważył, że ludność w okolicach Lwowa odnosiła się do żołnierzy niemieckich niezbyt życzliwie. Z drugiej jednak strony wojsko niemieckie zachowywało się wobec niej brutalnie, rekwirując żywność i kontrolując jej zapasy. Wielokrotnie W. Łęga widział kwity rekwizycyjne wystawiane przez dowcipnych żołnierzy z potwierdzeniem Świętego Mikołaja ${ }^{19}$.

Po roku trwania wojny kapelan zauważył zmiany w psychice żołnierzy, mianowicie zwiększającą się obojętność wobec zagrożenia życia, słowem: stopniowe przyzwyczajanie się do niebezpieczeństwa, chociaż walka pozycyjna, nieznajomość położenia wroga nierzadko prowadziły do rozstroju nerwowego wielu $\mathrm{z}$ nich ${ }^{20}$. Żołnierze bardzo dużą wagę przykładali do wizyt duszpasterskich, budując niejednokrotnie na linii frontu zamaskowane kapliczki i konfesjonały. $\mathrm{Na}$ ks. W. Łędze podczas celebrowanych nabożeństw niesamowite wrażenie wywoływał cichy śpiew pieśni, zapobiegający zdradzeniu swej obecności przed wrogiem. Największą jego zdaniem wagę do wizyt kapłańskich przywiązywali Westfalczycy i Nadreńczycy ${ }^{21}$.

Przez cały okres dotychczasowej służby ks. W. Łęga w rejestrach wojskowych figurował jako szeregowiec-sanitariusz. Zmieniono to po jego wniosku do Ministerstwa Wojny i od 25 VI 1915 r. zezwolono mu na noszenie munduru etatowego

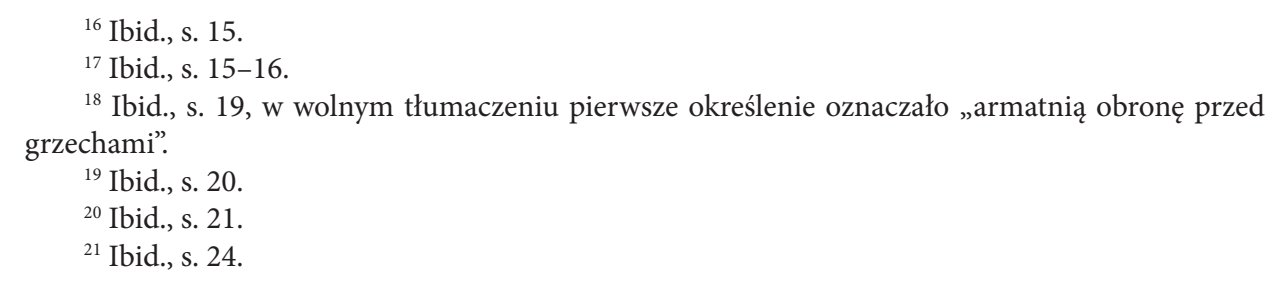


kapelana wojskowego, chociaż nadal pobierał żołd szeregowca. Zwrócił się więc do Inspekcji Etapowej 8. Armii z prośbą o przydział do duszpasterstwa. Rozpatrując ten wniosek, postawiono mu jednak warunek, aby przystąpił do niemieckiej katolickiej partii Centrum oraz zobowiązał się, że z pełnym zaangażowaniem będzie nauczał wyłącznie w języku niemieckim i czcił narodowe niemieckie święta. W. Łęga w swych wspomnieniach twierdzi, że odmówił spełnienia tych warunków i dlatego pozostał na dotychczasowym stanowisku ${ }^{22}$.

Posuwając się za frontem, kapliczka ks. W. Łęgi znalazła się we wrześniu 1915 r. na terenach Litwy, w Kownie i w Wilnie. Tu zauważył, że miejscowa ludność miejska znała doskonale język polski, a litewskim posługiwała się tylko ludność wiejska. Na ulicach Kowna słyszał mowę polską, litewską, niemiecką, rosyjską i żydowską, a ponadto miejscowi, wypowiadając jedno zdanie, posługiwali się kilkoma językami. Różnorodność wyznaniową miasta ukazywały także istniejące tam kościoły katolickie, zbory protestanckie, synagogi. Jego mieszkańcy mieli też, zdaniem kapelana, dość labilne określanie swojej narodowości. W zależności od kontekstu mogli być albo Litwinami, albo Polakami. Ks. W. Łęga twierdził, że nienawiści między obydwiema najliczniejszymi nacjami na tym terenie (polską i litewską) nie przytłumiła nawet wojna. Moim zdaniem było nawet jeszcze gorzej, wojna tę nienawiść wręcz rozbudziła. Wykorzystywało to niemieckie dowództwo, faworyzując stronę litewską. Sprowadzono do Prus Wschodnich pedagogów i dziennikarzy litewskich, którzy założyli litewskie seminarium nauczycielskie i litewskie czasopismo. Popierano też według ks. W. Łęgi aktywność gospodarczą Litwinów, utrudniając jednocześnie Polakom podejmowanie inicjatyw na tym polu ${ }^{23}$. Rzeczywiście chodziło zapewne wyłącznie o działalność gospodarczą, ponieważ już 28 VII 1915 r. Komendantura Frontu Wschodniego (Oberost) wydała rozporządzenie zakazujące działalności wszelkim organizacjom politycznym ${ }^{24}$.

W czasie pobytu w Kownie ks. W. Łęga zamieszkał w domu jednego z przywódców litewskiego ruchu narodowego (nie podaje nazwiska), od którego dowiedział się o aspiracjach państwowych Litwinów, uważających Polaków za zagrożenie dla tych dążeń. Według księdza Litwini woleli się związać z Niemcami lub Rosją aniżeli Polską $a^{25}$. Natomiast badacz dziejów Litwy Jerzy Ochmański stwierdził, że w tym czasie hasło niepodległości Litwy głosili emigranci litewscy, natomiast oficjalnie taki postulat został zgłoszony dopiero w uchwałach II Konferencji Litewskiej w Bernie na przełomie lutego i marca $1916 \mathrm{r}$. i powtórzony na zjeździe Litwinów w Hadze pod koniec kwietnia 1916 r. Podobnie twierdzą Marceli Kosman i Piotr Łossowski ${ }^{26}$.

${ }^{22}$ Ibid.

${ }^{23}$ Ibid., s. 25-26.

${ }^{24}$ Jerzy Ochmański, Historia Litwy, Wrocław-Warszawa-Kraków 1990 (wyd. 3), s. 263.

${ }^{25} \mathrm{~W}$. ŁĘGA, $Z$ mych wrażeń, s. 26-27.

${ }^{26}$ J. Ochmański, op.cit., s. 260-261; Piotr Łossowski, Po tej i tamtej stronie Niemna. Stosunki polsko-litewskie 1883-1939, Warszawa 1985, s. 83-84. 
Ksiądz W. Łęga zanotował też, że wkraczające do Wilna oddziały armii niemieckiej żydowskie kobiety witały kwiatami, co wykorzystały niemieckie gazety, uznając powyższe wydarzenie za dowód sympatii miejscowej ludności. Jednak większość wilnian zmianę panowania rosyjskiego na niemieckie przyjęła w biernym oczekiwaniu na kolejne wypadki. Część Polaków tam zamieszkujących zdołała jednak po opuszczeniu miasta przez Rosjan powołać milicję miejską, wprowadzić język polski do szkół i zorganizować polskie stowarzyszenia ${ }^{27}$. Zachęcająco w tym kierunku podziałały słowa dowodzącego oddziałami niemieckimi wkraczającymi do miasta, gen. Alexeia von Pfeila, który nazwał Wilno perłą Królestwa Polskiego. W odpowiedzi na to Blok Polskich Organizacji Demokratycznych 23 IX 1915 r. ogłosił deklarację o restytucji Wielkiego Księstwa Litewskiego w unii z Polskąą. Uaktywnił się powstały wówczas polski „Komitet Edukacyjny” w celu polszczenia szkolnictwa oraz Towarzystwo Polskiej Szkoły Ludowej. Wkrótce jednak Niemcy rozwiązali te organizacje i wprowadzili własny zarząd gospodarczy (Wirtschaftsauschuss) kontrolujący dystrybucję żywności, przez co tylko niewielka jej część docierała do ludności cywilnej. Z powodu niedożywienia ludzie omdlewali na ulicach, zdarzały się także przypadki śmierci głodowej ${ }^{29}$.

Na przełomie stycznia i lutego $1916 \mathrm{r}$. na Litwę dotarli przedstawiciele amerykańskiej komisji, dokonujący inspekcji terenów, które najwięcej ucierpiały w toku działań wojennych. Byli już przedtem w Belgii, Francji, Galicji i Królestwie Polskim. Wynikiem tej inspekcji była decyzja o przesłaniu na zagrożone głodem tereny żywności z USA. Strona brytyjska, obawiając się, że może wpaść w ręce niemieckie, nie przepuściła statków płynących na Litwę. W tych okolicznościach miejscowa ludność nie ukrywała niechęci do Niemców jako winowajców wszechobecnego głodu ${ }^{30}$.

Mimo to Litwini starali się wyeksponować swoje narodowe aspiracje, podkreślając litewski charakter Wilna. Sprzyjały temu dyrektywy płynące z „Ober-Ost”, nakłaniające niemieckich komendantów miasta do wykorzystania animozji narodowościowych w celu odwrócenia uwagi społeczeństwa od trudnej sytuacji aprowizacyjnej ${ }^{31}$.

Przebywając w tyglu narodowościowo-kulturowym: polsko-niemiecko-litewsko-białoruskim, W. Łęga rozpoczął swoiste dociekania antropologiczne, wykorzystując w tym celu także swoją kapłańską służbę w tamtejszym szpitalu, gdzie leczono jako rannych żołnierzy wielu narodowości, m.in. Rosjan. Prowadzone obserwacje doprowadziły go do wniosku, że ludzki charakter i osobowość są wypisane na twarzy i przejawiają się w ruchach oraz że są niezależne od narodowości ${ }^{32}$.

\footnotetext{
${ }^{27}$ W. ŁĘGA, Z mych wrażeń, s. 28.

${ }^{28}$ P. Łossowski, op.cit., s. 84.

${ }^{29} \mathrm{~W}$. ŁĘGA, Z mych wrażeń, s. 28-30.

${ }^{30}$ Ibid., s. 30.

${ }^{31}$ Ibid., s. 31.

${ }^{32}$ Ibid.
} 
$\mathrm{Z}$ nadejściem nowego roku, 1916, władze wojskowe oficjalnie nominowały ks. W. Łęgę do funkcji kapelana wojskowego (dotąd był sanitariuszem) ${ }^{33}$. Tym samym rozstał się ze służbą w samochodowej kapliczce i rozpoczął działalność duszpasterską w szpitalu polowym w Szumsku, miejscowości leżącej na drodze między Wilnem i Smorgoniami. Szpital ten oprócz leczenia żołnierzy obejmował także z polecenia władz wojskowych opieką lekarską okoliczną ludność cywilną, przeważnie białoruskiego pochodzenia. Miało to zapobiec zarażeniu się żołnierzy od miejscowych chorobami zakaźnymi ${ }^{34}$. Miejscowa ludność, żyjąca w odciętych od świata wioskach, nie miała zdaniem księdza pojęcia o medycynie i profilaktyce zdrowotnej i stąd ze sporą dozą nieufności odnosiła się do personelu medycznego szpitala. Panowało przekonanie, że kto znajdzie się w szpitalu, ten szybko umiera. W związku z tym, w celu zapobieżenia wybuchom epidemii i odseparowania osób już zarażonych, niejednokrotnie trzeba było używać siły ${ }^{35}$.

Oprócz posługi duchowej w szpitalu do obowiązków ks. W. Łęgi należała także praca duszpasterska w okolicznych jednostkach niemieckich i obozach jenieckich znajdujących się na obszarze między Wilnem a Smorgoniami. Bywał więc często w Miednikach, Kowalczukach, Rukojni i Wilejce. Dzięki znajomości kilku języków mógł w pełni zaspokajać potrzeby duchowe żołnierzy pochodzących $\mathrm{z}$ różnych zakątków wielonarodowej Rzeszy Niemieckiej i nawiązać z nimi bliższy kontakt ${ }^{36}$. Głównym jednak miejscem jego aktywności był szpital ${ }^{37}$.

W marcu 1916 r. dowództwo skarciło księdza za przesyłanie listów na teren cesarstwa Romanowów i zaproponowało mu dobrowolne zrzeczenie się funkcji kapelana wojskowego ${ }^{38}$. Okazało się to tylko pretekstem, ponieważ głównym powodem niezadowolenia władz wojskowych był fakt wygłaszania przez W. Łęgę kazań w języku polskim w wileńskim kościele św. Jakuba, utrzymywanie kontaktów towarzyskich z miejscową społecznością polską i prowadzenie korespondencji po polsku. Został on zdemobilizowany w trybie natychmiastowym 1 IV 1916 r. $^{39}$

Przez Wilno ks. W. Łęga wrócił na Pomorze i pelplińska kuria biskupia przydzieliła go do pełnienia posługi duszpasterskiej na stanowisku wikarego w Grucznie niedaleko Świecia nad Wisłą. Tam wrócił do pracy naukowej, rozpoczynając ją od kompletowania literatury naukowej i czasopism, do których nie miał dostępu na froncie. Korzystał z pomocy księży: Pawła Czaplewskiego z Borzyszkowa, Stanisława Hoffaua z Pinczyna i Benedykta Dybowskiego ze Lwowa ${ }^{40}$. Nie jest naszym

${ }^{33} \mathrm{KM}$, TN, sygn. 286/186, nr 4, 8.

${ }^{34}$ W. ŁĘGA, Z mych wrażeń, s. 31.

${ }^{35}$ Ibid., s. 32.

${ }^{36}$ Ibid., s. 33.

${ }^{37}$ Ibid.

${ }^{38}$ Ibid., s. 34.

${ }^{39} \mathrm{KM}$, TN, sygn. $286 / 186, \mathrm{nr} 4$.

${ }^{40}$ Ibid., list ks. S. Hoffaua z 10 IV 1916 r. w sprawie otrzymania teki czasopism; ibid., nr 12-13, 15, listy ks. B. Dybowskiego w sprawie zakupu XII tomu czasopisma „Lud” z 1911 r.; ibid., nr 14, list ks. P. Czaplewskiego z 16 IV 1916 r. zawierający informacje bibliograficzne. 
celem analiza działalności naukowej ks. W. Łęgi, jednak należy podkreślić, że jedenastomiesięczny pobyt w Grucznie zaowocował po zakończeniu wojny licznymi publikacjami (o czym traktuje cytowany wyżej artykuł J. Powierskiego).

Niepowodzenia państw centralnych na froncie, zwłaszcza w toku wyniszczających walk pozycyjnych na Zachodzie, doprowadziły do braków kadrowych w armii. Zaczęto więc sięgać po rezerwy. Stąd też niespełna w rok po demobilizacji, 10 III 1917 r. W. Łęga został powtórnie powołany do służby wojskowej ${ }^{41}$. Ponownie przeszkolono go w koszarach i przydzielono na 9 miesięcy do grudziądzkiego szpitala garnizonowego jako sanitariusza. W celu uzupełnienia strat na froncie zachodnim 1 I 1918 r. przydzielono go do służby w 402. Pułku Piechoty, tzw. grudziądzkim, walczącym na terenie Francji ${ }^{42}$. Przez Berlin i Metz dotarł do niewielkiej stacji we francuskim Rembecourt, którego okolica wydawała się księdzu niemal idylliczna, gdyby nie pomruk dział artyleryjskich. Po przenocowaniu następnego dnia dotarł do jednostki przeznaczenia w Thiaucourt. Tymczasowo objął obowiązki pisarza $\mathrm{w}$ pułkowym punkcie sanitarnym, ale wkrótce został zmuszony do wypełniania zwykłych obowiązków sanitariusza. Po pewnym czasie lekarz sztabowy wysłał go jednak do służby w okopach, gdzie zobaczył prawdziwe oblicze wojny pozycyjnej: kikuty drzew, kule artyleryjskie świszczące nad głowami, prowizoryczne schrony niedające odpowiedniego zabezpieczenia, braki żywnościowe ${ }^{43}$. Nie wykonywał tam jednak obowiązków sanitariusza, lecz przydzielono go do noszenia części karabinów maszynowych. Złożył protest i mianowano go pisarzem lekarza batalionowego. Zauważył wtedy, że wśród żołnierzy, niezależnie od narodowości, panuje zobojętnienie, negatywne postrzeganie wojny, nawet wśród tych, którzy niedawno przejawiali gorący patriotyzm. Wówczas, na wiosnę 1918 r., odporność psychiczna żołnierzy była na skraju wytrzymałości, a hasła pruskiego militaryzmu przestały na nich oddziaływać. Myśleli tylko o szybkiej, bezbolesnej śmierci lub szczęśliwym ocaleniu. Niewielu wierzyło, że uda im się przeżyć to piekło. W czasie wiosennej ofensywy ententy poddawały się całe oddziały Niemców, tych samych, którzy na początku wojny byli gotowi walczyć do ostatniej kropli krwi ${ }^{44}$.

W kwietniu 1918 r. 402. Pułk Piechoty, w którym służył W. Łęga, został przeniesiony do Saint-Mihiel, gdzie znajdował się jeden z fortów wchodzących w skład umocnień twierdzy Verdun. To sześciotysięczne miasto znajdowało się w zasięgu artylerii francuskiej, choć ta, chcąc oszczędzić mieszkańców, punktowo ostrzeliwała jedynie sztab niemiecki lub kolumny transportowe. Było to możliwe dzięki miejscowej ludności informującej Francuzów o położeniu wojsk niemieckich. W trakcie przemarszu na kolejne pozycje w okolice Chateau Thierry nad Marną w Szampanii, z braku dostaw żywnościowych, żołnierze 402. Pułku zjadali zabite

${ }^{41}$ Ibid., nr 4, zestawienie przebiegu służby w okresie od 1 I 1915 r. do 13 V 1919 r.

${ }^{42}$ Ibid.

${ }^{43}$ W. ŁĘGA, Z mych wrażeń, s. 37; Jan Mazurkiewicz, Los żolnierza, red. Jerzy DzIEwicki, Gdańsk 1975, s. 14; Ernst JüNGer, Książe piechoty. (W nawałnicy żelaza), tłum. Janusz GA£AdyK, Warszawa 1938 (wyd. 2), s. 29, 36.

${ }^{44}$ W. ŁĘGA, Z mych wrażeń, s. 37-38. 
zwierzęta pociągowe - osły, konie. Po dotarciu do tunelu kolejowego (Tunel Kronprinza) byli zabezpieczeni przed artylerią, ale w tym wilgotnym obiekcie swoje żniwo zaczęła zbierać epidemia „hiszpanki” ${ }^{45}$. Tym bardziej że znacznie pogorszyło się i tak dotąd marne zaopatrzenie w żywność i w szeregach armii panował głód. Ciepłe pożywienie było podawane tylko raz na dobę i ze względu na niebezpieczeństwo wypatrzenia przez wroga dymu z kuchni polowych dopiero około godziny 23. Taka sytuacja przygnębiała niemieckich żołnierzy, tym bardziej że dowiedzieli się, iż naprzeciwko nich stacjonuje „świeża” 2. Dywizja armii amerykańskiej ${ }^{46}$.

Dnia 1 VII 1918 r. artyleria amerykańska przez pół dnia ostrzeliwała pozycje niemieckie. Długotrwały ostrzał powodował niebywałe przygnębienie w niemieckich okopach - żołnierze zaczęli się pokładać w łóżkach, czekając tam na śmierć. Kiedy okazało się, że zostali okrążeni, wszyscy rzucili broń i czekali na pojawienie się Amerykanów. Ci po rewizji jeńców i zabraniu im kosztowności, m.in. żelaznych krzyży (szczególnie popularny materiał na pamiątki dla żołnierzy ententy), uformowali wziętych do niewoli w kolumny marszowe w celu doprowadzenia do $\mathrm{sztabu}^{47}$.

Amerykanie, zdaniem W. Łęgi, wykazywali wówczas niesłychaną bezwzględność wobec niemieckich żołnierzy, nie zwracali też uwagi na to, że było wśród nich także wielu innej narodowości niż niemiecka. Przy okazji ksiądz zauważył różnice w reakcji żołnierzy różnych narodowości na odniesione rany i ból. Stwierdził, że najspokojniej zachowywali się Amerykanie, Francuzi stękali i wzdychali, natomiast jeden $\mathrm{z}$ Włochów odreagowywał ból śpiewaniem, którego tonacja wzrastała $\mathrm{z}$ nasilającym się cierpieniem ${ }^{48}$.

W miejscowości La Ferté Amerykanie przekazali niemieckich jeńców Francuzom, którzy ponownie ich zrewidowali, zabierając wszystkie zachowane dotąd przedmioty. Tutaj po raz pierwszy zapytano jeńców, z której części Niemiec pochodzą. Wyróżniono Bawarczyków, Saksończyków, Nadreńczyków, Hannowerczyków, Polaków klasyfikując jedynie jako „Nieprusaków”49. Kolejny raz jeńcy zostali wysłani w dalszą drogę - bez jedzenia i możliwości ugaszenia pragnienia; kolumna ciągnęła wzdłuż brzegów Marny, by w końcu dotrzeć do obozu karnego. Składał się on jedynie z czterech baraków niemających podłogi, nie było w nim łóżek ani czegokolwiek do spania. Poza tym roiło się w nich od wszelkiego robactwa, które nie pozwalało na sen dłuższy niż godzinę. Dzienne racje żywnościowe stanowił kawał zeschniętego chleba, soczewica na obiad, a na kolację kubek czarnej kawy. Pragnienie gasili jeńcy wodą z wystawionej beczki, która w znacznej części była wypełniona błotem. W. Łęga został wyznaczony do służby w lazarecie.

${ }^{45}$ Ibid., s. 40-41. Por. Bernard Poтryкus, Wspomnienia Kaszuba spod Verdun, Warszawa 1939 (wyd. 2), s. 27-37, 40.

${ }^{46} \mathrm{~W}$. ŁĘGA, $Z$ mych wrażeń, s. 42-43.

${ }^{47}$ Ibid., s. $45-46$.

${ }^{48}$ Ibid., s. $47-48$.

${ }^{49}$ Ibid., s. 50. 
W odróżnieniu od innych baraków na wyposażeniu lazaretu znajdowały się łóżka i dery, będące jednak wylęgarnią wszelkiego robactwa, którego było tam więcej niż w pozostałych budynkach. Jeńcy trafiali do lazaretu najczęściej wskutek wygłodzenia, braku snu, a po jakimś czasie pojawili się pierwsi chorzy na „hiszpankę". Remedium na wszelkie dolegliwości stanowiła mokra chustka, którą francuscy sanitariusze uderzali chorego po twarzy, co budziło pacjenta z letargu i kończyło proces leczenia ${ }^{50}$.

Kolejnym miejscem pobytu ks. W. Łęgi był obóz amerykański, do którego w pierwszym etapie transportowano jeńców koleją. Wagony, w których ich umieszczono, służyły przedtem do wożenia siarki, stąd panował w nich smród i zaduch, dokuczliwy tym bardziej że ładowano po 50 osób do każdego z nich. Po dotarciu na miejsce (Gièvres) kolejny raz zrewidowano jeńców, ale potem wysłano do kąpieli oraz zdezynfekowano zawszone mundury, na ten czas ubierając ich w odzież zastępczą. Mieszkali pod namiotami. Tu po raz pierwszy otrzymali dobre wyżywienie. Śniadanie zwykle stanowiła zupa z kukurydzy („Quaker”), czasami z ryżu, kawałek chleba i kawa. Porcje były spore, a żywność jakościowo dobra - przyrządzali ją kucharze różnych narodowości, więc była rozmaita. U żołnierzy odwykłych od normalnego wyżywienia wywoływało to niekiedy dolegliwości żołądkowe ${ }^{51}$.

Po krótkim pobycie w tym obozie transportem kolejowym przewieziono wyposażonych $\mathrm{w}$ prowiant jeńców do Tours. W czasie marszu z dworca kolejowego do miejsca zakwaterowania jeńcy doświadczyli na sobie nienawiści francuskiej ludności cywilnej do Niemców. Eskorta francuska musiała brutalnie potraktować swoich ziomków, aby nie doszło do linczu na jeńcach. W osadzie St. Pierre des Corps, pod Tours, jeńcy mieli sami zbudować swoje lokum. Francuzi już tak dobrze nie karmili jak Amerykanie. W celu zaspokojenia głodu niemieccy jeńcy dokonywali kradzieży żywności, zwłaszcza ziemniaków z pobliskiego pola. Po trzech tygodniach sytuacja się jednak zmieniła - Amerykanie dosłali żywność. W obozie pobudowano kuchnię, stołówkę, baraki biurowe, łazienki, magazyny, izbę chorych, warsztaty rzemieślnicze, boisko sportowe, pojawiło się kino, zorganizowano nawet dwa teatry, których aktorami byli jeńcy ${ }^{52}$.

Dowódcą obozu w St. Pierre był kapitan (wkrótce major) Cough, przejawiający głęboki podziw dla niemieckiej kultury i stąd wyróżniał autentycznych Niemców, powołując samorząd jeniecki złożony z typowych feldfeblów i równocześnie zabraniając eksponowania innego pochodzenia narodowego. Wniosek jeńców narodowości polskiej o zgromadzenie ich w jednym baraku w celu ułatwienia im wstąpienia do formującej się armii polskiej gen. J. Hallera został przez komendanta odrzucony, podobnie jak prośba o zezwolenie na odprawianie nabożeństw po polsku ${ }^{53}$.

\footnotetext{
${ }^{50}$ Ibid., s. 51-52. Podobnie byli odżywiani jeńcy w angielskich obozach, zob. J. MAZURKIEwicz, op.cit., s. 102.

${ }^{51}$ W. ŁĘGA, Z mych wrażeń, s. 54.

${ }^{52}$ Ibid., s. $57,63-64$.

${ }^{53}$ Ibid., s. 62. 
Władysław Łęga zaobserwował wyjątkową życzliwość pełniących służbę w obozie żołnierzy amerykańskich wobec jeńców niemieckich. Tłumaczył to m.in. faktem, że wielu Amerykanów miało niemieckie korzenie ${ }^{54}$. Zauważył też, że niezbyt dobrze wyglądały relacje między Amerykanami a Francuzami. Pierwsi byli spokojni, nawet flegmatyczni, drudzy zaś gorączkowi i gadatliwi. Dochodziło między nimi do zatargów, a nawet bójek. Jedna z nich wynikła na skutek wprowadzenia przez Francuzów zakazu wychodzenia żołnierzy do miasta na przepustki, w związku z licznymi przypadkami zarażeń wenerycznych. W trakcie tej bójki zginęło kilku Amerykanów. O tym incydencie pisały nawet amerykańskie gazety, wypominając Francuzom niewdzięczność za pomoc i uratowanie przed klęską ${ }^{55}$.

Jesienią 1918 r. do obozu zaczęły docierać książki nadsyłane przez Międzynarodowy Czerwony Krzyż, wszystkie w języku niemieckim. Od listopada, chociaż nieregularnie, dosyłano egzemplarze wychodzącego we Francji czasopisma, które według W. Łęgi nazywało się „Polak”. W owym czasie w Paryżu wychodził tygodnik „Polonja” redagowany przez Wacława Gąsiorowskiego, być może o niego chodziło. Jednak ze względu na brak cenzora znającego język polski wiele egzemplarzy trafiało na śmietnik, skąd czasami udawało się je odzyskaćs.

Poprzednie ciężkie przeżycia wojenne, a w 1918 r. monotonia życia obozowego powodowały u wielu jeńców symptomy załamania nerwowego i zaburzeń psychicznych, w związku z czym trafiali oni do szpitala w Tours. Pozwolono ks. W. Łędze ich odwiedzać i duchowo wspierać. Dzięki temu dwa razy w tygodniu opuszczał teren obozu eskortowany przez żołnierzy amerykańskich, którzy także chętnie korzystali z tej okazji, ponieważ zabroniono Amerykanom wstępu do miasta. Przyczyną wprowadzenia tego zakazu było stwierdzenie wielu przypadków chorób wenerycznych i obawa, że rozprzestrzenią się one wśród żołnierzy ${ }^{57}$.

Pod koniec listopada 1918 r. władze obozowe zezwoliły na urządzanie spotkań jeńców narodowości polskiej. Na tych spotkaniach odbywały się wykłady, toczono dyskusje, śpiewano polskie pieśni. W zorganizowanym konkursie deklamacyjnym wzięło udział około 130 Polaków w niemieckim mundurze. Pozwolono także na urządzenie polskiego wieczoru sylwestrowego ${ }^{58}$. Te polskie spotkania nie podobały się wielu Niemcom, którzy gromadzili notatki na temat, ich zdaniem, antyniemieckiej postawy Polaków - żołnierzy niemieckich, aby po wojnie postawić ich przed niemieckimi sądami za zdradę ojczyzny. Wynika z tego, że nie przewidywali oni jakichkolwiek zmian granicznych, a zwłaszcza odzyskania przez Polskę niepodległości. Ich aktywność spowodowała, iż w końcu lutego 1919 r. władze obozowe zakazały polskich spotkań. Wzmogło to napięcie między Polakami i Niemcami - dochodziło do kłótni, a nawet rękoczynów ${ }^{59}$.

\footnotetext{
${ }^{54}$ Ibid., s. 72.

${ }^{55}$ Ibid., s. 73.

${ }^{56}$ Ibid., s. 63.

${ }^{57}$ Ibid., s. 68.

${ }^{58}$ Ibid., s. 69.

${ }^{59}$ Ibid., s. 70.
} 
Dopiero na krótko przed zakończeniem wojny udało się jeńcom polskiego pochodzenia uzmysłowić Amerykanom swoją odmienność narodową. Jednak sporządzenie spisu Polaków poruczono niemieckim pisarzom, którzy uważali, że Polakiem jest tylko ten, kto jest obywatelem państwa polskiego, a za takowe uznawali Królestwo Polskie i obszar zaboru rosyjskiego. W związku z tym na liście pojawili się Niemcy, Estończycy, a pominięto wszystkich Polaków z zaboru austriackiego i pruskiego, których liczbę w obozie W. Łęga szacował na około 300. Natomiast około 100 Polaków znalazło się na liście repatriacyjnej niemieckich sanitariuszy, których wysyłano do Niemiec. Wśród nich był W. Łęga, wobec którego niemieccy „aktywiści” obozowi dysponowali, przynajmniej jego zdaniem, całymi plikami oskarżeń o zdradę, prowadzenie polskiej agitacji, nawoływanie do służby w polskiej armii. Polacy złożyli protest przeciwko repatriacji, argumentując to faktem trwającej wojny polsko-niemieckiej (chodziło o powstanie wielkopolskie) i 62 $\mathrm{z}$ nich pozostawiono nadal $\mathrm{w}$ obozie ${ }^{60}$.

W styczniu 1919 r. według oficjalnych zapowiedzi miał się pojawić w obozie St. Pierre des Corps, oficer mający przeprowadzić zaciąg do armii Hallera. Dotarł dopiero w maju i dokładnie 13 tegoż miesiąca ks. W. Łęga został zwolniony z przeszło dziewięciomiesięcznej niewoli. Otrzymał odszkodowanie za okres obozowy, które wynosiło dla sanitariuszy jednego dolara, czyli pięć franków dzien$n^{6}{ }^{61}$. Łącznie z obozu, zdaniem W. Łęgi, zwolniono 300 Polaków zgłaszających akces do armii Hallera. Tego samego dnia w Tours ubrano ich w mundury „błękitnej armii" i wyekspediowano do Paryża, aby zameldowali się w Podintendenturze Polsko-Francuskiej Misji Wojskowej i Naczelnym Dowództwie Armii Polskiej we Francji ${ }^{62}$.

Kolejne dwa tygodnie razem $\mathrm{z}$ kompanami spędził W. Łęga na zwiedzaniu miasta. Wywoływali oni zainteresowanie mieszkańców Paryża swoimi rogatywkami i mundurami. Polacy zamieszkali w polskim kasynie przy Rue de Bois de Boulogne, w którym widywano mundury prawie wszystkich armii państw ententy. Jedni opowiadali o walkach francusko-rosyjskich pod Odessą, drudzy wyrażali swe żale na sposób traktowania Polaków w Niemczech. Polaków zadziwiała niewiedza Amerykanów o Polsce - niektórzy z nich uznawali, że Polska i Czechosłowacja to jedno, inni wyobrażali sobie Polskę jako egzotyczny kraj, jak Chiny czy Meksyk. Po podpisaniu deklaracji o wstąpieniu do armii w Kwaterze Głównej Armii Polskiej w Paryżu, co było równoznaczne z przyjęciem polskiego obywatelstwa, W. Łęga w asyście trzech poruczników udał się do polskiego obozu szkoleniowego w Sillé le Guillaume. Tam zostali zaprzysiężeni na oficerów wojska polskiego, otrzymali żołd i przydział wojskowy do 7. Dywizji Strzelców stacjonującej w Lure pod Belfortem. Stamtąd ks. W. Łęga został odesłany do oddziału sanitarnego w pobliskim Lyoffans, gdzie objął obowiązki kapelana. Oddział był złożony w większości z Po-

${ }^{60}$ Ibid., s. 72.

${ }^{61} \mathrm{KM}$, TN, sygn. 286/186, $\mathrm{nr} 4,8$.

${ }^{62}$ Ibid.; W. ŁĘGA, Z mych wrażeń, s. 74. 
laków, byłych żołnierzy armii austriackiej, którzy dostali się do włoskiej niewoli. Natomiast wśród lekarzy było tylko dwóch Polaków, resztę stanowili Francuzi ${ }^{63}$.

Władysław Łęga zaprzyjaźnił się z miejscowym proboszczem, który podzielił się z polskim księdzem problemem, z jakim borykała się większość francuskich parafii. Mianowicie męska część francuskich wiernych bardzo rzadko uczęszczała na nabożeństwa niedzielne. Natomiast wszyscy żołnierze z oddziału W. Łęgi zjawili się na sumie w miejscowym kościele, wywołując sporą sensację ${ }^{64}$. Dnia 15 VII 1919 r. ks. W. Łęga został mianowany kapelanem 7. Dywizji, a następnie 49. Pułku Piechoty Strzelców Kresowych. W początku czerwca 1919 r. oddziały te wyruszyły przez Niemcy do Polski.

Zaprezentowana relacja ks. W. Łęgi jest jedyną spisaną przez Polaka pełniącego służbę jako sanitariusz i kapelan w armii niemieckiej, ukazującą specyfikę takiej sytuacji. Mimo posiadania pełnoprawnego obywatelstwa Cesarstwa Niemieckiego polskość ks. W. Łęgi powodowała jego gorsze traktowanie przez niemieckie władze wojskowe. Dla szeregowych żołnierzy był zaś jedynie tym, który niósł pomoc medyczną i duchową, a nieporozumienia pojawiły się dopiero po klęsce Niemiec podczas pobytu w obozach jenieckich. Paradoksem było, że jako jeniec w obozach francuskim i amerykańskim ks. W. Łęga był postrzegany wyłącznie jako żołnierz niemiecki. Za Polaków uznawano tych, którzy pochodzili z Królestwa Polskiego i z Galicji, często nawet niezależnie od przynależności etnicznej.

prof. dr hab. Szczepan Wierzchosławski

Instytut Historii i Archiwistyki

Uniwersytet Mikołaja Kopernika w Toruniu

e-mail: szwierz@umk.pl

${ }^{63} \mathrm{~W}$. ŁEGGA, Z mych wrażeń, s. 76.

${ }^{64}$ Ibid., s. 76-77. 


\section{DIE SOLDATISCHEN ABENTEUER DES PRIESTERS WŁADYSŁAW ŁĘGA WÄHREND DES 1. WELTKRIEGS}

\section{Zusammenfassung}

Schlüsselwörter: 1914-1919, Sanitätsdienst, Heereskaplan, preußische Armee, Front, Gefangenschaft, Kriegsgefangenenlager, Armee des Generals Józef Haller

Der Artikel schildert die Schicksale eines polnischen Priesters und preußischen und deutschen Staatsbürgers, der 1915 als Sanitätssoldat an die Front einberufen wurde, obwohl er ein Recht auf den Offiziersrang hatte, und der danach die Funktion eines Sanitätskaplans ausübte. Auf der Grundlage seiner Erzählung wird von der Stimmung berichtet, die damals unter den Soldaten herrschte: von den Beziehungen zwischen den deutschen und polnischen Nationalitäten, von der Lage in den Gebieten, in die Władysław Łęga kam (Litauen, Frankreich), aber auch von der Einstellung der dortigen Zivilbevölkerung zur deutschen Armee. Hauptsächlich geht es jedoch um die Wiedergabe der persönlichen Erlebnisse eines Polen in einer fremden Armee. Nacheinander erfährt man etwas vom Elend des Daseins als deutscher Soldat in amerikanischer und französischer Gefangenschaft, von dem freundschaftlichen Verhältnis der amerikanischen Soldaten zu den Deutschen und dem kühlen Verhältnis zu ihren französischen Verbündeten sowie davon, dass sie die polnische Nationalität nicht als solche wahrnahmen. Aus der Erzählung geht auch die feindliche Einstellung der deutschen Soldaten gegenüber den polnischen Unabhängigkeitshoffnungen und gegenüber ihren Frontkameraden polnischer Abstammung hervor, die versuchten sich der polnischen Armee von Józef Haller anzuschließen, die in Zusammenarbeit mit der Entente entstanden war. Eine ähnliche Einstellung zu dieser Frage hatten auch die Amerikaner, die den Polen die Verwirklichung solcher Absichten erschwerten. 
THE MILITARY VICISSITUDES OF POLISH PRIEST WŁADYSŁAW ŁĘGA DURING WW I

\author{
Summary
}

Key words: $1914-1918$, sanitary service, military chaplains, the Prussian army, the military front, captivity, camps of prisoners of war, the army of General Józef Haller

The article presents the vicissitudes of a Polish priest, a citizen of Prussia and Germany, who was called up in 1915 as a private - a paramedic despite the fact that he was entitled to hold the rank of an officer; he later held the position of chaplain-sanitary. Through the perspective of his narrative, the atmosphere among the soldiers, the relations between the Poles and the Germans, the situation in the territories where Władysław Łęga was stationed (Lithuania, France), and the attitude of the local civilian population to the German army are described. However, the major element is the depiction of the personal vicissitudes of a Polish soldier in the German army. The reader learns about the poverty the soldier experienced under American and French captivity as a German soldier; next, the reader discovers that American soldiers exhibited a friendly attitude to the Germans, but were quite reserved towards the French; the author also reveals the fact that the Americans could not distinguish the Polish nationality. The account also discloses the hostile attitude of German soldiers towards Polish aspirations to regain independence and, in general, towards their companions of Polish origin who were trying to sign up for the Polish army of Gen. Józef Haller created in cooperation with the Triple Entente. A similar attitude towards this issue was exhibited by the Americans who hindered the actions of the Poles.

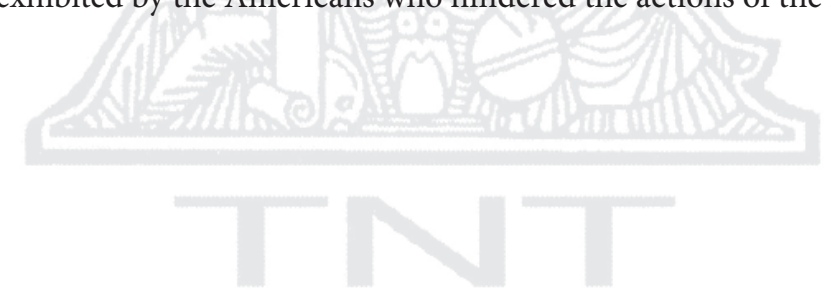

